\title{
ZAPOTRZEBOWANIE NA WSPARCIE SAMORZĄDÓW SZKOLNYCH
}

\section{Abstract \\ The demand to support student governments}

The paper is focused on the problems of student governments. A student government is a place where students learn the mains principles of democracy. The task of a school is to identify natural leaders and help them develop their competences. A school should prepare good leaders who could work at social and public areas. The result of this process depends on how teachers are prepared to work with students. In this paper we aim to identify advantages and disadvantages of student governments. The study was made at secondary schools in the north-western Poland. In total, 464 students and 41 teachers were studied. The results suggest how to support student governments. The study indicates that both students and teachers have limited knowledge about the mains principles and tasks of student governments. The respondents differ in their perception of advantages and disadvantages of student governments.

Keywords: student government, demand for support, prevention

\section{Streszczenie}

Artykuł poświęcony jest problematyce samorządności szkolnej. To obszar działań szkoły, który ma nauczyć zasad demokracji. W ramach tej edukacji zadaniem szkoły jest zidentyfikowanie naturalnych liderów oraz stworzenie im warunków do rozwoju ich kompetencji, aby w przyszłości mogli w sposób odpowiedzialny pełnić funkcje społeczne czy instytucjonalne. Skuteczność tego procesu zależy od przygotowania nauczycieli i doboru treści edukacyjnych do pracy z młodzieżą. Stąd też w pracy podjęto zadanie zidentyfikowania atutów i ograniczeń samorządności szkolnej w środowisku uczniów wybranych szkół ponadpodstawowych województwa zachodniopomorskiego. Pytania o zapotrzebowanie na wsparcie samorządu szkolnego zadano uczniom i nauczycielom. Łącznie przebadano 464 uczniów i 41 nauczycieli. Wyniki pozwoliły na określenie kierunku działań wspierających samorządność szkolną. Wskazują na ograniczoną wiedzę na temat istoty samorządu szkolnego i jego zadań, zarówno w percepcji uczniów, jak i nauczycieli. Badani też inaczej spostrzegają atuty i ograniczenia liderów samorządu.

Slowa kluczowe: samorządność szkolna, badanie zapotrzebowania, wsparcie, psychoprofilaktyka 


\section{Wprowadzenie}

Wsłuchując się w komentarze na temat działania ludzi zarządzających państwem, samorządem czy też firmą lub instytucją, w której pracujemy, możemy usłyszeć wiele cierpkich i krytycznych słów. Niestety niejednokrotnie adekwatnych i trafnych. U polityków, samorządowców, naszych szefów pojawia się wiele deficytów w kompetencjach osobowościowych, społecznych, a nawet profesjonalnych. Wśród tych krytycznych komentarzy niezmiernie mało jest refleksji na temat tego, gdzie jest źródło tych deficytów. Czy uczenie zarządzania na studiach to odpowiedni moment, aby ukształtować człowieka w jego głębszych warstwach? $\mathrm{Z}$ perspektywy psychologii rozwojowej to pytanie nabiera charakteru retorycznego. Dynamiczny rozwój kluczowych kompetencji osobistych i społecznych odbywa się na etapie edukacji szkolnej.

Szkoła to przestrzeń, w której prowadzi się wiele działań na rzecz uczniów. To środowisko, w którym człowiek ma wzrastać w sferze fizycznej, psychicznej, społecznej i duchowej. Wzrost ten zachodzić ma poprzez edukację, wychowanie i profilaktykę. Jednym z wielu obszarów, gdzie młody człowiek może się tak wszechstronnie rozwijać, jest samorząd szkolny.

\section{Samorząd uczniowski - czyli co?}

Samorząd uczniowski to demokratyczna organizacja zrzeszająca wszystkich uczniów danej szkoły w celu reprezentowania ich interesów wobec nauczycieli, rodziców i administracji szkolnej. Do tematu samorządności uczniowskiej można znaleźć wiele odniesień w dokumentach prawnych. Najpełniej zakres kompetencji samorządu uczniowskiego określa art. 55 Ustawy o systemie oświaty [UoSO, 1991, art. 55]. Znajduje się on w rozdziale 4, dotyczącym społecznych organów w systemie oświaty. A oto jego wybrane punkty:

Art. 55:

1. W szkole i placówce działa samorząd uczniowski, zwany dalej „samorządem”.

2. Samorząd tworzą wszyscy uczniowie szkoły lub placówki.

3. Zasady wybierania i działania organów samorządu określa regulamin uchwalany przez ogół uczniów w głosowaniu równym, tajnym i powszechnym. Organy samorządu są jedynymi reprezentantami ogółu uczniów.

4. Regulamin samorządu nie może być sprzeczny ze statutem szkoły lub placówki.

5. Samorząd może przedstawiać radzie szkoły lub placówki, radzie pedagogicznej oraz dyrektorowi wnioski i opinie we wszystkich sprawach szkoły lub placówki, w szczególności dotyczące realizacji podstawowych praw uczniów.

Wymienione akty prawne wyznaczają ramy funkcjonowania samorządu szkolnego. Są one tak sprofilowane, aby samorząd był miejscem nauki odpowiedzialności za społeczność, w której się żyje. Dzięki samorządności szkoła może wychowywać do takich wartości, jak demokracja, wolność, odpowiedzialność i troska o innych. 


\section{Cechy skutecznego samorządu szkolnego}

Koncepcja samorządu uczniowskiego wyrasta z idei, zgodnie z którą wszyscy członkowie określonej społeczności lokalnej są współodpowiedzialni za jakość jej funkcjonowania [por. Kuzitowicz, 2017; Stolarska, 2005]. Zgodnie z takim rozumieniem każdy samorząd uczniowski winien się charakteryzować kilkoma podstawowymi cechami:

- jego zarząd powinny tworzyć osoby będące demokratycznie wybraną reprezentacją ogółu uczniów danej szkoły;

- powinien on mieć jednoznacznie określony zakres praw i obowiązków, skutkiem którego stawałby się rzeczywistym współgospodarzem szkoły i partnerem dla dorosłych pracowników szkoły;

- każdy członek samorządu uczniowskiego ma zachowane poczucie bezpieczeństwa, konieczne do skutecznego wywiązywania się ze swoich obowiązków;

- samorząd uczniowski jest postrzegany przez nauczycieli i rodziców jako partner w tworzeniu zdrowych warunków do rozwoju, a nie jako przeciwnik w tworzeniu wygodnych warunków pracy dla personelu szkolnego;

- wzajemne stosunki między dorosłym kierownictwem a samorządem młodzieżowym powinny być regulowane przez:

- rzeczywisty podział kompetencji i obowiązków,

- autentyczną współodpowiedzialność i współkierownictwo młodzieży;

- załatwianie przez młodzież jej własnych spraw - z własnej inicjatywy, własnymi sposobami, w nastawieniu na własne cele [por. Gaś, 2013; Kamiński, 1985].

Zbigniew Bronisław Gaś [2013] konfrontuje powyższe założenia z rzeczywistością i proponuje wyróżnić siedem typów samorządów działających we współczesnej szkole:

- Samorząd reprezentacyjny,

- Samorząd dyspozycyjny (konformistyczny),

- Samorząd konfrontacyjny,

- Samorząd nieistniejący,

- Samorząd rotacyjny,

- Samorząd rywalizacyjny,

- Samorząd współdziałający [Gaś, 2013: 10].

U podstaw tej klasyfikacji leżą: znaczenie samorządu w społeczności szkolnej, sposób wyboru, reprezentatywność oraz sposób funkcjonowania. Stąd też, w zależności od nasilenia głównych kryteriów funkcjonowania samorządów, można wyróżnić ich różne typy. Każdy z nich ma inną specyfikę i potencjał działania, a w konsekwencji atuty i deficyty.

Samorząd reprezentacyjny - którego zarząd złożony jest z zaproponowanych przez nauczycieli uczniów wyróżniających się w nauce i w zachowaniu (a często również 
urodą i posturą), będących wizytówką szkoły. Pełni on z reguły funkcje reprezentacyjne wobec lokalnego środowiska oraz jest współodpowiedzialny za organizowanie uroczystości i obrzędów szkolnych. Posiada on akceptację grona pedagogicznego oraz nie cieszy się zaufaniem uczniów;

Samorząd dyspozycyjny (konformistyczny) - którego zarząd złożony jest z uczniów wyznaczonych przez nauczycieli, prezentujących zachowania konformistyczne i uległe wobec dorosłego personelu szkolnego. Jego podstawową funkcją jest jednokierunkowa transmisja (od nauczycieli do uczniów) zaleceń i postanowień grona pedagogicznego. Samorząd taki nie cieszy się szacunkiem i zaufaniem ani nauczycieli, ani uczniów;

Samorząd konfrontacyjny - którego zarząd złożony jest z uczniów reprezentujących opozycję szkolną (często grupy podkulturowe), prowadzący nieustającą walkę ze wszystkim, co reprezentuje normy, zasady i zalecenia świata dorosłych. Na skutek swojego działania wyzwala on agresję i wrogość grona pedagogicznego (manifestowane w formie otwartych i ukrytych działań represyjnych), zaś ze strony młodzieży otrzymuje wsparcie (ale głównie na poziomie „drugiego życia”). Często jest manipulowany przez różnorodne ośrodki władzy w szkole, zaś wśród rówieśników jest czynnikiem konfliktorodnym;

Samorząd nieistniejący - działający w szkołach o wysokim poziomie autokratyzmu nauczycieli. Zarząd takiego samorządu złożony jest z uczniów nie potrafiących powiedzieć NIE ani rówieśnikom, ani nauczycielom, bez inicjatywy w działaniu, wycofujących się z życia szkoły, unikających ponoszenia jakiejkolwiek odpowiedzialności, „oddelegowanych” przez swoich rówieśników do zarządu. W sytuacjach konfliktowych jest on wygodny dla każdej ze strony, albowiem pełni wówczas rolę kozła ofiarnego;

Samorząd rotacyjny - będący faktycznie samorządem klasowym, który na ściśle określony czas (np. dwa tygodnie, miesiąc) zostaje przemianowany decyzją dyrektora szkoły w zarząd samorządu szkolnego, a po tym okresie zostaje zastąpiony przez samorząd kolejnej klasy itd. Strategia taka jest bezpieczna dla grona pedagogicznego (pozwala na łatwą manipulację i nie dopuszcza do szerszego zaangażowania się młodzieży we współtworzenie środowiska szkolnego) oraz destrukcyjna dla uczniów (prowokuje niezdrową rywalizację międzyklasową, uniemożliwia jednostkom aktywnym społecznie długofalowego działania na rzecz środowiska szkolnego, wypacza ideę samorządności). Faktycznie więc szkoła taka niszczy ideę samorządu uczniowskiego;

Samorząd rywalizacyjny - którego zarząd złożony jest z uczniów o skłonnościach przywódczych i dominatywnych, skoncentrowany jest na rywalizacji z dorosłymi pracownikami szkoły. Jego podstawowym celem jest przejęcie władzy w szkole, stąd podejmowane działania podważają kompetencje i autorytet nauczycieli, budzą poczucie zagrożenia i prowokują u grona pedagogicznego wycofywanie się z kontaktów lub przemoc. Od samorządu konfrontacyjnego różni się tym, iż jego celem jest zdobycie władzy w szkole, a nie walka dla samej walki;

Samorząd współdziałający - którego zarząd złożony jest z uczniów wybranych w demokratycznych wyborach ogólnoszkolnych (z prezentacją programów wyborczych), cieszących się autorytetem zarówno rówieśników, jak i grona pedagogiczne- 
go. Ukierunkowany jest on na realizację zadań, widzi potrzebę współdziałania z dorosłymi pracownikami szkoły oraz czuje się współodpowiedzialny za wszystko, co dzieje się w środowisku szkolnym. Takie działanie samorządu jest możliwe dopiero wówczas, gdy wszystkie grupy tworzące lokalne środowisko danej szkoły (tzn. grono pedagogiczne, pracownicy administracyjni, rodzice oraz młodzież) chcą współdziałać w tworzeniu warunków do pełnego rozwoju [Gaś, 2013: 34-36].

Powyższe założenia teoretyczne prowokują do badania, jakiego rodzaju samorządność dominuje w polskich szkołach. Który z powyższych typów jest najbardziej reprezentatywny dla samorządności szkolnej i co zrobić, aby wykorzystać tę metodę wychowania do rozwoju dzieci i młodzieży. Problem jest poznanie jakości funkcjonowania i zidentyfikowanie obszarów wsparcia samorządów szkolnych na wybranych przykładach ze środowiska szkół szczecińskich.

\section{Metodologia}

Celem opracowania jest zbadanie zapotrzebowania na działania wspomagające samorządność uczniowską. W tym celu w artykule postawiono następujące badania badawcze:

1. Jakie są atuty i ograniczenia u osób zaangażowanych w działalność samorządu uczniowskiego w percepcji uczniów?

2. Jakie są atuty i ograniczenia u osób zaangażowanych w działalność samorządu uczniowskiego w percepcji nauczycieli?

3. Jakie jest zapotrzebowanie na wsparcie samorządności w szkole?

Badania wykonano wśród uczniów i nauczycieli czterech szkół w Szczecinie, a mianowicie dwóch gimnazjalnych, zespołu szkół ponadgimnazjalnych i liceum ogólnokształcącego. Badanie było dobrowolne i anonimowe. Przeprowadzono jej w październiku i listopadzie 2012 roku.

Do badań wykorzystano dwa narzędzia autorskie Zbigniewa Bronisława Gasia: Ankieta PASU-ZU i Ankieta PASU-ZN. Zostały one opracowane w wersji elektronicznej przez Roberta Porzaka.

Uczniowie wchodzili do sal komputerowych ze swoim opiekunem i wypełniali elektroniczne ankiety. Każdy z nich otrzymał indywidualny kod dostępu i nie miał wglądu w odpowiedzi innych uczestników badań.

Odpowiedzi otwarte skategoryzowano i dokonano obliczeń statystycznych za pomocą pakietu statystycznego SPSS. 


\section{Wyniki}

\section{Charakterystyka badanych ze względu na zmienne demograficzne}

W badaniu uczestniczyło 464 uczniów i 41 nauczycieli (łącznie 505 osób) z czterech szkół w Szczecinie, tj. dwóch gimnazjów, zespołu szkół ponadgimnazjalnych i liceum ogólnokształcącego (zob. tabela 1).

\section{Badani uczniowie}

W grupie uczniów znalazło się 215 chłopców i 249 dziewcząt, a więc większość stanowiły dziewczęta (53,7\%). Spośród badanych szkół najwięcej uczniów uczestniczących w badaniu pochodziło z liceum ogólnokształcącego. Uczniowie tej szkoły stanowili 50,5\% wszystkich badanych. Najmniej uczniów zaangażowanych w badanie pochodziło z zespołu szkół (77 uczniów, tj. 15,2\%).

Tabela 1

Zmienne demograficzne badanych osób

\begin{tabular}{|c|c|c|c|c|c|}
\hline \multirow{2}{*}{\multicolumn{2}{|c|}{ Zmienne demograficzne }} & \multicolumn{4}{|c|}{ Grupa } \\
\hline & & \multicolumn{2}{|c|}{ uczniowie } & \multicolumn{2}{|c|}{ nauczyciele } \\
\hline & & $\mathbf{n}$ & $\%$ & n & $\%$ \\
\hline \multirow{3}{*}{ Płeć } & M & 215 & 46,3 & 6 & 14,6 \\
\hline & K & 249 & 53,7 & 35 & 85,4 \\
\hline & ogółem & 464 & 100,0 & 41 & 100,0 \\
\hline \multirow{5}{*}{ Szkoła } & gimnazjum & 75 & 16,2 & 7 & 17,1 \\
\hline & gimnazjum & 84 & 18,1 & 7 & 17,1 \\
\hline & zespół szkół & 65 & 14,0 & 12 & 29,3 \\
\hline & LO & 240 & 51,7 & 15 & 36,6 \\
\hline & ogółem & 464 & 100,0 & 41 & 100,0 \\
\hline \multirow{3}{*}{$\begin{array}{l}\text { Doświadczenie działania } \\
\text { w samorządzie }\end{array}$} & nie & 307 & 66,2 & 29 & 70,7 \\
\hline & tak & 157 & 33,8 & 12 & 29,3 \\
\hline & ogółem & 464 & 100,0 & 41 & 100,0 \\
\hline
\end{tabular}

Źródło: opracowanie własne.

Młodzież biorąca w badaniu reprezentuje w porównywalnym stopniu klasy pierwsze, drugie i trzecie. Najmniej jest osób z klas czwartych, wynika to z faktu, że jedynie w zespole szkół występuje czwarty poziom kształcenia i z tej szkoły pochodzą badani (zob. tabela 2).

$\mathrm{W}$ jednym z gimnazjów najwięcej uczniów pochodzi z klas trzecich (45,3\%), a najmniej z klas drugich (17,3\%). Podobnie sytuacja przedstawia się w zespole szkól, gdzie stosunek uczniów klas trzecich i drugich wynosi 32,3 do 20. Natomiast 
w drugim gimnazjum najwięcej uczniów jest z klas pierwszych $(36,9 \%)$, a najmniej z klas trzecich (29,8\%). Z kolei w LO dominują uczniowie klas drugich (37,9\%), a najmniej liczni są badani z klas trzecich $(29,6 \%)$.

Spośród przebadanych uczniów jedna trzecia $(33,5 \%)$ miała doświadczenie pracy w samorządzie szkolnym. Podobnie jest w środowisku nauczycieli - jedynie 33,8\% miało doświadczenie współpracy z samorządem. Można uznać, że podejmowana opieka nad samorządem ma charakter rotacyjny, co nie sprzyja przekazywaniu doświadczeń i budowaniu tradycji tej organizacji.

\section{Badani nauczyciele}

Badaniami zostali objęci także nauczyciele jako osoby wspierające wszelkie działania młodzieży w szkole. Łącznie w badaniu wzięło udział 41 wychowawców, przy czym najwięcej z liceum ogólnokształcącego (15 osób). Z obu gimnazjów w badanie zaangażowało się jedynie po 7 nauczycieli. Wśród badanych nauczycieli dominowały kobiety (35 z 41 badanych). Tylko blisko jedna trzecia z nich miała doświadczenie działania w samorządzie szkolnym.

Tabela 2

Częstotliwość udziału w badaniach wyróżniona ze względu na szkoły

\begin{tabular}{|c|c|c|c|c|c|c|c|c|c|c|c|}
\hline \multirow{3}{*}{\multicolumn{2}{|c|}{$\begin{array}{l}\text { Częstotliwość udziału } \\
\text { w badaniach }\end{array}$}} & \multicolumn{10}{|c|}{ Szkola } \\
\hline & & \multicolumn{2}{|c|}{$\underset{\text { I }}{\text { gimnazjum }}$} & \multicolumn{2}{|c|}{$\begin{array}{c}\text { gimnazjum } \\
\text { II }\end{array}$} & \multicolumn{2}{|c|}{$\begin{array}{c}\text { zespół } \\
\text { szkół }\end{array}$} & \multicolumn{2}{|c|}{ LO } & \multicolumn{2}{|c|}{ ogólem } \\
\hline & & $\mathbf{n}$ & $\%$ & $\mathrm{n}$ & $\%$ & $\mathbf{n}$ & $\%$ & $\mathrm{n}$ & $\%$ & $\mathrm{n}$ & $\%$ \\
\hline \multirow{3}{*}{ Grupa } & uczniowie & 75 & 91,5 & 84 & 92,3 & 65 & 84,4 & 240 & 94,1 & 464 & 91,9 \\
\hline & nauczyciele & 7 & 8,5 & 7 & 7,7 & 12 & 15,6 & 15 & 5,9 & 41 & 8,1 \\
\hline & ogółem & 82 & 100,0 & 91 & 100,0 & 77 & 100,0 & 255 & 100,0 & 505 & 100,0 \\
\hline \multirow{3}{*}{ Płeć } & $\mathrm{M}$ & 36 & 43,9 & 47 & 51,6 & 29 & 37,7 & 109 & 42,7 & 221 & 43,8 \\
\hline & K & 46 & 56,1 & 44 & 48,4 & 48 & 62,3 & 146 & 57,3 & 284 & 56,2 \\
\hline & ogółem & 82 & 100,0 & 91 & 100,0 & 77 & 100,0 & 255 & 100,0 & 505 & 100,0 \\
\hline \multirow{5}{*}{ Klasa } & 1 & 27 & 36,0 & 31 & 36,9 & 17 & 26,2 & 78 & 32,5 & 153 & 33,0 \\
\hline & 2 & 13 & 17,3 & 28 & 33,3 & 13 & 20,0 & 91 & 37,9 & 145 & 31,3 \\
\hline & 3 & 34 & 45,3 & 25 & 29,8 & 21 & 32,3 & 71 & 29,6 & 151 & 32,5 \\
\hline & 4 & 1 & 1,3 & 0 & 0,0 & 14 & 21,5 & 0 & 0,0 & 15 & 3,2 \\
\hline & ogółem & 75 & 100,0 & 84 & 100,0 & 65 & 100,0 & 240 & 100,0 & 464 & 100,0 \\
\hline \multirow{3}{*}{$\begin{array}{l}\text { Doświadczenie } \\
\text { działania } \\
\text { w samorządzie }\end{array}$} & nie & 57 & 69,5 & 58 & 63,7 & 60 & 77,9 & 161 & 63,1 & 336 & 66,5 \\
\hline & tak & 25 & 30,5 & 33 & 36,3 & 17 & 22,1 & 94 & 36,9 & 169 & 33,5 \\
\hline & ogółem & 82 & 100,0 & 91 & 100,0 & 77 & 100,0 & 255 & 100,0 & 505 & 100,0 \\
\hline
\end{tabular}

Źródło: opracowanie własne. 
Wśród badanych nauczycieli najwięcej jest osób, które przepracowały w zawodzie co najmniej 16 lat i więcej (zob. tabela 3). Takich osób jest 19 (blisko połowa). Niewiele mniej, bo 17 osób (ponad dwie piąte) przepracowało od 8 do 15 lat. Pozostali nauczyciele legitymują się stażem pracy w zawodzie mniejszym niż 7 lat.

Podsumowując, przeważająca większość badanych nauczycieli to osoby ze średnim lub dużym doświadczeniem edukacyjnym, choć bez doświadczenia w pracy z samorządem szkolnym.

Tabela 3

Staż w zawodzie nauczycieli biorących udział w badaniu w poszczególnych szkołach

\begin{tabular}{|c|c|c|c|c|c|c|c|c|c|c|}
\hline \multirow{3}{*}{ Staż w zawodzie } & \multicolumn{10}{|c|}{ Szkoła } \\
\hline & \multicolumn{2}{|c|}{ LO } & \multicolumn{2}{|c|}{$\underset{\text { I }}{\text { gimnazjum }}$} & \multicolumn{2}{|c|}{$\begin{array}{c}\text { gimnazjum } \\
\text { II }\end{array}$} & \multicolumn{2}{|c|}{ zespół szkół } & \multicolumn{2}{|c|}{ ogółem } \\
\hline & $\mathrm{n}$ & $\%$ & $\mathbf{n}$ & $\%$ & $\mathbf{n}$ & $\%$ & $\mathrm{n}$ & $\%$ & $\mathbf{n}$ & $\%$ \\
\hline 16 lat i powyżej & 10 & 24,4 & 4 & 9,76 & 2 & 4,88 & 3 & 3,9 & 19 & 46,34 \\
\hline $8-15$ lat & 5 & 12,2 & 2 & 4,88 & 5 & 12,2 & 5 & 12,2 & 17 & 41,46 \\
\hline 4-7 lat & 0 & 0,0 & 1 & 2,44 & 0 & 0,0 & 3 & 7,32 & 4 & 9,76 \\
\hline Do 3 lat & 0 & 0,0 & 0 & 0,0 & 0 & 0,0 & 1 & 2,44 & 1 & 2,44 \\
\hline Ogółem & 15 & 36,6 & 7 & 17,08 & 7 & 17,08 & 12 & 25,86 & 41 & 100 \\
\hline
\end{tabular}

Źródło: opracowanie własne.

\section{Podsumowanie}

Badani nauczyciele to $\mathrm{w}$ zdecydowanej większości osoby doświadczone, pozostające w zawodzie ponad 8 lat. Miały już czas na zapoznanie się ze specyfiką pracy szkoły. W badaniu wzięło udział więcej nauczycieli o bardzo długim stażu pracy. Sugerować to może, że małe zainteresowanie badaniami samorządności w szkole jest wynikiem pewnej tradycji i oznacza małe jej znaczenie dla badanych.

Z powyższych danych wynika, że zaangażowanie w badanie ze strony grona pedagogicznego jest raczej niewielkie. Stąd konieczne jest wsparcie samorządności poprzez działania zewnętrzne. Pojawia się tu potrzeba wsparcia edukacyjnego środowiska nauczycielskiego oraz wzmocnienie znaczenia samorządności uczniowskiej poprzez działania instytucji nadzoru, takich jak Kuratorium Oświaty czy też Ministerstwo Edukacji Narodowej.

\section{Atuty i ograniczenia uczniów działających w samorządzie szkolnym w percepcji uczniów i nauczycieli}

W tabeli 4 zaprezentowano pożądane cechy uczniów i nauczycieli działających w samorządzie szkolnym. Najwięcej badanych uczniów wskazało na takie cechy 
samorządowca jak dojrzałość i odpowiedzialność (44\%) oraz twórczość i kreatywność (41,1\%). Na dalszych pozycjach znalazły się sprawność w działaniu, pozytywne usposobienie i umiejętności interpersonalne.

Tabela 4

Pożądane cechy uczniów pracujących w obszarze samorządności

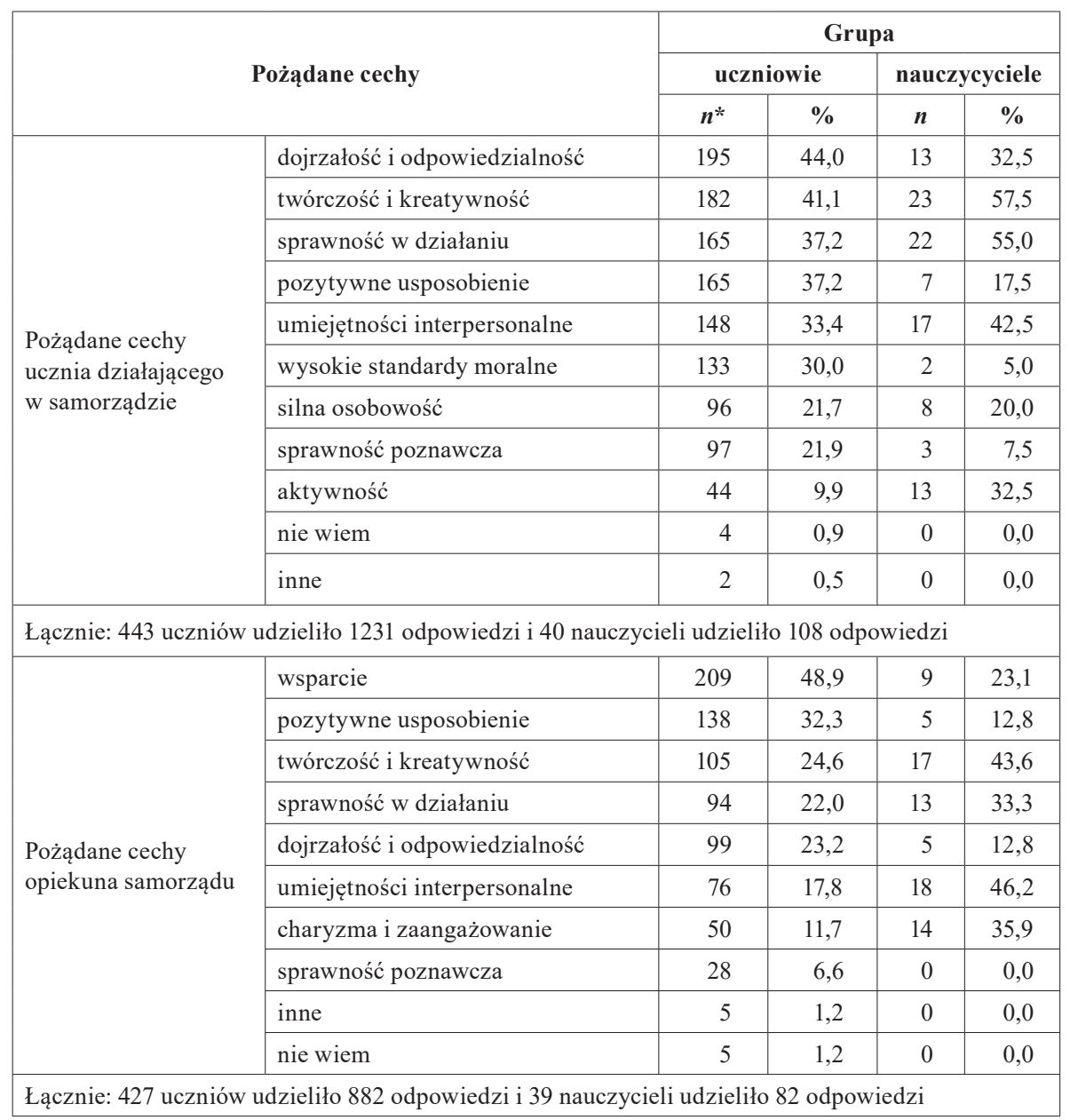

* Odpowiedzi na pytanie otwarte wielokategorialne. Osoba badana mogła udzielić więcej niż jednej odpowiedzi, dlatego wyniki nie sumuja się do 100\%. Odsetki częstości występowania danej odpowiedzi wyliczono jako procent liczby respondentów (uczniów lub nauczycieli), którzy udzielili odpowiedzi na to pytanie.

Źródło: opracowanie własne. 
Z kolei w osobie opiekuna samorządu młodzież ceni najbardziej możliwość uzyskania wsparcia (48,9\%). Inne pożądane cechy opiekuna to pozytywne usposobienie (32,3\%), a w dalszej kolejności twórczość i kreatywność (24,6\%), sprawność w działaniu (22\%) oraz dojrzałość i odpowiedzialność $(23,2 \%)$.

Najwięcej badanych nauczycieli widzi u uczniów z samorządu potrzebę takich cech jak twórczość i kreatywność (23 nauczycieli na 41 badanych). Ponad połowa z nich widzi potrzebę sprawnego działania. Nieznacznie mniej nauczycieli (17 badanych) jako pożądane u samorządowców szkolnych spostrzega umiejętności interpersonalne. Blisko jedna trzecia pedagogów wskazuje jako pożądane dojrzałość i odpowiedzialność oraz aktywność. Najrzadziej wybierane przez wychowawców były wysokie standardy moralne, na które wskazały jedynie 2 osoby, oraz sprawność poznawcza (3 osoby na 41 badanych).

Z kolei do pożądanych cech opiekuna samorządu blisko połowa wychowawców zalicza umiejętności interpersonalne oraz twórczość i kreatywność. Blisko jedna trzecia nauczycieli dostrzega też potrzebę takich cech jak charyzma i zaangażowanie oraz sprawność w działaniu. Najrzadziej wybieraną kategorią jest sprawność poznawcza (żaden badany nie wybrał tej kategorii) oraz dojrzałość i odpowiedzialność, a także pozytywne usposobienie (po 5 badanych wybrało tę odpowiedź).

$Z$ powyższych analiz wynika, że uczniowie inaczej postrzegają pożądane cechy osób działających w samorządzie szkolnym niż ich wychowawcy. Młodzież oczekuje sprawności w funkcjonowaniu osobistym, natomiast nauczyciele koncentrują się raczej na umiejętnościach.

\section{Braki uczniów działających w samorządzie szkolnym}

Kolejnym badanym obszarem są braki uczniów działających w samorządzie szkolnym (zob. tabela 5). Uczniowie i nauczyciele są zgodni, że to, czego najbardziej brakuje przedstawicielom samorządu szkolnego, to twórczość i kreatywność, sprawność w działaniu oraz charyzma i zaangażowanie. W dalszej kolejności pojawia się też silna osobowość, a więc umiejętności liderskie. Znaczna grupa uczniów $(14,4 \%)$ nie wie nic na temat braków rówieśników pełniących obowiązki w samorządzie.

Wśród nauczycieli jest też grupa osób (ponad jedna dziesiąta), która wskazuje na brak aktywności uczniów działających w samorządzie.

\section{Braki opiekunów samorządu szkolnego}

Dokonując analizy ograniczeń opiekunów samorządów, można dostrzec szereg ciekawych prawidłowości (tabela 6). Znaczący procent badanych z obu grup zgadza się co do tego, że niczego im nie brakuje (25,4\% uczniów i 8 z 41 badanych nauczycieli). Pozostała część uczniów wskazuje na braki opiekunów samorządu w zakresie twórczości i kreatywności oraz wyrozumiałości i cierpliwości (odpowiednio 20,1\% i 15,3\%). Ponad co dziesiąty uczeń nie potrafi wskazać żadnych braków u opiekunów samorządów szkolnych. 
Braki u uczniów działających w samorządzie szkolnym

\begin{tabular}{|c|c|c|c|c|c|}
\hline \multirow{2}{*}{\multicolumn{2}{|c|}{ Braki u uczniów dzialających w samorządzie szkolnym }} & \multicolumn{4}{|c|}{ Grupa } \\
\hline & & \multicolumn{2}{|c|}{ uczniowie } & \multicolumn{2}{|c|}{ nauczyciele } \\
\hline & & $n^{*}$ & $\%$ & $n^{*}$ & $\%$ \\
\hline \multirow{13}{*}{$\begin{array}{l}\text { Czego brakuje uczniom } \\
\text { działającym w samorzą- } \\
\text { dzie? }\end{array}$} & twórczość i kreatywność & 151 & 37,4 & 12 & 33,3 \\
\hline & sprawność w działaniu & 88 & 21,8 & 12 & 33,3 \\
\hline & charyzma i zaangażowanie & 69 & 17,1 & 12 & 33,3 \\
\hline & silna osobowość & 66 & 16,3 & 8 & 22,2 \\
\hline & nie wiem & 58 & 14,4 & 1 & 2,8 \\
\hline & wysokie standardy moralne & 46 & 11,4 & 0 & 0,0 \\
\hline & umiejętności interpersonalne & 44 & 10,9 & 1 & 2,8 \\
\hline & sprawność poznawcza & 25 & 6,2 & 0 & 0,0 \\
\hline & wsparcie & 14 & 3,5 & 0 & 0,0 \\
\hline & aktywność & 7 & 1,7 & 5 & 13,9 \\
\hline & niczego & 0 & 0,0 & 2 & 5,6 \\
\hline & $\begin{array}{l}\text { umiejętności perswazji i negoc- } \\
\text { jacji }\end{array}$ & 1 & 0,2 & 1 & 2,8 \\
\hline & inne & 1 & 0,2 & 0 & 0,0 \\
\hline
\end{tabular}

* Odpowiedzi na pytanie otwarte wielokategorialne. Osoba badana mogła udzielić więcej niż jednej odpowiedzi, dlatego wyniki nie sumuja się do 100\%. Odsetki częstości występowania danej odpowiedzi wyliczono jako procent liczby respondentów (uczniów lub nauczycieli), którzy udzielili odpowiedzi na to pytanie.

Źródło: opracowanie własne.

Z kolei blisko jedna trzecia nauczycieli za główne ograniczenie w działaniu opiekunów uważa brak czasu. Jedna piąta wskazuje na inne przyczyny spoza wyróżnionych kategorii. Tylko nieliczni wskazują na braki w funkcjonowaniu osobowościowym i profesjonalnym opiekunów.

Wśród wypowiedzi nauczycieli dostrzegalne jest rozdrobnienie odpowiedzi i tendencja do unikania przyjęcia określonego stanowiska. Może to wynikać w niejasności zadań stojących przed opiekunem. Wskazane jest podnoszenie świadomości i podkreślenie znaczenia roli opiekuna w działaniu samorządu szkolnego. 
Braki u nauczycieli opiekujących się samorządem szkolnym

\begin{tabular}{|l|l|c|c|c|c|}
\hline \multicolumn{2}{|c|}{ Braki u opiekunów samorządu szkolnego } & \multicolumn{4}{c|}{ Grupa } \\
\cline { 3 - 6 } & & \multicolumn{2}{|c|}{ uczniowie } & \multicolumn{2}{c|}{ nauczyciele } \\
\cline { 2 - 6 } & niczego & 105 & 25,4 & 8 & 22,2 \\
\hline \multirow{4}{*}{$\begin{array}{l}\text { Czego brakuje opieku- } \\
\text { nom samorządu? }\end{array}$} & twórczość i kreatywność & 83 & 20,1 & 2 & 5,6 \\
\cline { 2 - 6 } & wyrozumiałość i cierpliwość & 63 & 15,3 & 2 & 5,6 \\
\cline { 2 - 6 } & nie wiem & 46 & 11,1 & 3 & 8,3 \\
\cline { 2 - 6 } & czas & 10 & 2,4 & 11 & 30,6 \\
\cline { 2 - 6 } & wysokie standardy moralne & 19 & 4,6 & 0 & 0,0 \\
\cline { 2 - 6 } & dojrzałość i odpowiedzialność & 13 & 3,1 & 0 & 0,0 \\
\cline { 2 - 6 } & silna osobowość & 10 & 2,4 & 0 & 0,0 \\
\cline { 2 - 6 } & umiejętności interpersonalne & 0 & 0,0 & 1 & 2,8 \\
\hline
\end{tabular}

* Odpowiedzi na pytanie otwarte wielokategorialne. Osoba badana mogła udzielić więcej niż jednej odpowiedzi, dlatego wyniki nie sumuja się do 100\%. Odsetki częstości występowania danej odpowiedzi wyliczono jako procent liczby respondentów (uczniów lub nauczycieli), którzy udzielili odpowiedzi na to pytanie.

Źródło: opracowanie własne.

\section{Zapotrzebowanie na wsparcie samorządności szkolnej}

Kolejnym obszarem analiz jest zidentyfikowanie potrzeb szkoleniowych członków samorządów uczniowskich. Jedną z analizowanych kwestii są trudne sprawy, z jakimi spotykają się członkowie samorządów szkolnych (zob. tabela 7).

Największa grupa badanych uczniów (24,1\%) nie jest w stanie wymienić spraw, którymi zajmują się ich koledzy w samorządzie. Duża grupa uczniów uważa, że ich koledzy z samorządu szkolnego zajmują się jedynie organizowaniem imprez i pozyskiwaniem finansów (odpowiednio uważa tak 18,8\% i 13\% badanych uczniów).

$\mathrm{Z}$ kolei badani nauczyciele na pierwszym miejscu wymieniają problem braku zaangażowania uczniów w działania samorządu (16 nauczycieli na 41 badanych). Inną trudnością, którą spostrzegają, jest pozyskiwanie finansów na działania samorządów (jedna trzecia badanych). Blisko jedna piąta badanych nauczycieli nie jest w stanie wymienić żadnego problemu, z jakim spotykają się uczniowie działający w samorządzie szkolnym. 
Trudne sprawy, z jakimi spotyka się samorząd uczniowski

\begin{tabular}{|c|c|c|c|c|c|}
\hline \multirow{3}{*}{\multicolumn{2}{|c|}{$\begin{array}{c}\text { Sprawy, którymi powinien się zajmować } \\
\text { samorząd szkolny }\end{array}$}} & \multicolumn{4}{|c|}{ Grupa } \\
\hline & & \multicolumn{2}{|c|}{ uczniowie } & \multicolumn{2}{|c|}{ nauczyciele } \\
\hline & & $n^{*}$ & $\%$ & $n^{*}$ & $\%$ \\
\hline \multirow{13}{*}{$\begin{array}{l}\text { Z jakimi trudnymi spra- } \\
\text { wami styka się samorząd } \\
\text { uczniowski? }\end{array}$} & nie wiem & 100 & 24,1 & 6 & 16,2 \\
\hline & inne & 79 & 19,0 & 3 & 8,1 \\
\hline & organizowanie imprez & 78 & 18,8 & 0 & 0,0 \\
\hline & środki finansowe & 54 & 13,0 & 10 & 27,0 \\
\hline & brak zaangażowania uczniów & 34 & 8,2 & 16 & 43,2 \\
\hline & przemoc & 25 & 6,0 & 0 & 0,0 \\
\hline & żadnymi & 23 & 5,5 & 0 & 0,0 \\
\hline & pomysły na działanie & 22 & 5,3 & 1 & 2,7 \\
\hline & używki & 16 & 3,9 & 1 & 2,7 \\
\hline & wyposażenie szkoły & 13 & 3,1 & 0 & 0,0 \\
\hline & brak czasu & 6 & 1,4 & 1 & 2,7 \\
\hline & personel szkoły & 4 & 1,0 & 2 & 5,4 \\
\hline & integracja & 2 & 0,6 & 0 & 0,0 \\
\hline
\end{tabular}

* Odpowiedzi na pytanie otwarte wielokategorialne. Osoba badana mogła udzielić więcej niż jednej odpowiedzi, dlatego wyniki nie sumuja się do 100\%. Odsetki częstości występowania danej odpowiedzi wyliczono jako procent liczby respondentów (uczniów lub nauczycieli), którzy udzielili odpowiedzi na to pytanie.

Źródło: opracowanie własne.

Kolejnym badanym obszarem potrzeb uczniów z samorządu szkolnego są treści szkoleniowe niezbędne do poprawy jakości funkcjonowania samorządów (zob. tabela 8). W tym zakresie świadomość uczniów jest raczej niska. Znacząca liczba badanych osób (ponad jedna trzecia) nie jest w stanie wymienić żadnego obszaru szkoleniowego lub jest bardzo niespójna w odpowiedziach. Pozostali koncentrują się bardziej na swoich oczekiwaniach niż potrzebach uczestników, wskazując na organizację imprez (21,6\%). Około 10\% badanych wskazuje na organizację i zarządzanie oraz na pracę w grupie, a więc stricte umiejętności liderskie.

Jedna trzecia badanych nauczycieli wskazuje na potrzebę szkolenia uczniów w aktywizowaniu środowiska szkolnego. Co dziesiąty badany nauczyciel nie jest w stanie wskazać żadnej potrzeby szkoleniowej. 
Potrzeby szkoleniowe dla członków samorządu

\begin{tabular}{|c|c|c|c|c|c|}
\hline \multirow{3}{*}{\multicolumn{2}{|c|}{ Potrzeby szkoleniowe }} & \multicolumn{4}{|c|}{ Grupa } \\
\hline & & \multicolumn{2}{|c|}{ uczniowie } & \multicolumn{2}{|c|}{ nauczyciele } \\
\hline & & $n *$ & $\%$ & $n^{*}$ & $\%$ \\
\hline \multirow{11}{*}{$\begin{array}{l}\text { Co powinno znaleźć się } \\
\text { w programie szkoleniowym } \\
\text { dla członków samorządu } \\
\text { uczniowskiego? }\end{array}$} & nie wiem & 118 & 34,5 & 4 & 11,1 \\
\hline & organizacja imprez & 74 & 21,6 & 2 & 5,6 \\
\hline & inne & 66 & 19,3 & 9 & 25 \\
\hline & organizacja i zarządzanie & 31 & 9,1 & 9 & 25 \\
\hline & praca w grupie & 36 & 10,5 & 1 & 2,8 \\
\hline & $\begin{array}{l}\text { aktywizowanie środowiska } \\
\text { szkolnego }\end{array}$ & 9 & 2,6 & 12 & 33,3 \\
\hline & negocjacje & 10 & 2,9 & 2 & 5,6 \\
\hline & komunikacja & 7 & 2 & 2 & 5,6 \\
\hline & rozwiązywanie problemów & 8 & 2,3 & 0 & 0 \\
\hline & $\begin{array}{l}\text { pozyskiwanie środków } \\
\text { finasowych }\end{array}$ & 4 & 1,2 & 3 & 8,3 \\
\hline & $\begin{array}{l}\text { uczenie się odpowiedzial- } \\
\text { ności }\end{array}$ & 6 & 1,8 & 1 & 2,8 \\
\hline
\end{tabular}

* Odpowiedzi na pytanie otwarte wielokategorialne. Osoba badana mogła udzielić więcej niż jednej odpowiedzi, dlatego wyniki nie sumuja się do 100\%. Odsetki częstości występowania danej odpowiedzi wyliczono jako procent liczby respondentów (uczniów lub nauczycieli), którzy udzielili odpowiedzi na to pytanie.

Źródło: opracowanie własne.

\section{Wnioski i zalecenia}

Samorząd szkolny to organizacja uczniowska, która ma określony dokumentami status i zadania do spełnienia. Z badań wynika, że wiedza na temat istoty samorządności szkolnej jest niewystarczająca zarówno wśród uczniów, jak i nauczycieli. W związku z powyższym wskazane byłoby ukazanie, poprzez działania informacyjne i edukacyjne, znaczenia samorządności szkolnej dla rozwoju uczniów, szkoły, jak i społeczności lokalnej. W ramach tych działań cenne byłoby ukazanie znaczenia samorządu dla prawidłowego życia społeczności szkolnej oraz wiedzy o jego istocie i zasadach funkcjonowania.

Nauczyciele i uczniowie byli pytani o pożądane cechy młodzieży zaangażowanej w pracę samorządu szkolnego. Nauczyciele biorący udział w badaniu oczekują od samorządowców przede wszystkim kreatywności i twórczości 
oraz sprawności w działaniu. Z kolei badani uczniowie oczekują, że ich koledzy pracujący w samorządzie szkolnym wykażą się dojrzałością i odpowiedzialnością, a następnie kreatywnością i twórczością w działaniu. Z analizy tego zapotrzebowania można wysnuć wniosek, że pedagodzy traktują samorząd nieco instrumentalnie, koncentrując się na sferze działania, a nie postawach uczniów. Bardziej wymagający pod tym względem są uczniowie, którzy oczekują od swoich kolegów z samorządu pewnego poziomu dojrzałości psychicznej. Wobec powyższego wskazana byłaby praca $z$ gronem pedagogicznym nad dookreśleniem oczekiwań i opracowaniem spójnego profilu przedstawiciela samorządu szkolnego.

Kolejnym analizowanym obszarem samorządności szkolnej były słabości uczniów działających w tej organizacji. Obie badane grupy są zgodne, że samorządowcom szkolnym brakuje przede wszystkim kreatywności i twórczości, aktywności i zaangażowania w pracę oraz silnej osobowości. Takie cechy opisują sprawnego lidera, stąd wskazane byłoby objęcie młodzieży szkolnej warsztatami uczącymi kompetencji liderskich. Takie szkolenia mogłyby zaowocować przygotowaniem młodych ludzi do podejmowania i sprawnego wywiązywania się z funkcji liderskich w społeczności lokalnej.

Badana młodzież i ich nauczyciele pytani byli także o słabości opiekunów samorządów szkolnych. Największa grupa badanych nauczycieli uważa, że opiekunom samorządów brakuje czasu. Równie duża grupa badanych uważa, że opiekunowie mają wszystko, co im potrzebne do pracy z samorządem. Reasumując, wśród nauczycieli nie ma zapotrzebowania na rozwój w zakresie pracy z samorządem szkolnym.

Nieco inne zdanie mają badani uczniowie. Uważają oni, że opiekunom samorządów szkolnych brakuje twórczości i kreatywności oraz wyrozumiałości i cierpliwości. Jedna czwarta uczniów uważa, że nauczyciele mają wszystkie kompetencje do wspierania samorządności w szkole. Sugerowane zmiany w pracy opiekunów samorządności powinny pójść w kierunku wzmocnienia ważności tego zadania i docenienia ich pracy.

W ramach prowadzonych badań pytano respondentów o ich potrzeby szkoleniowe. Większość uczniów nie wie, co jest potrzebne ich kolegom z samorządu. Z kolei nauczyciele wskazują, w zakresie potrzeb, głównie zaangażowanie uczniów i środki finansowe. Potwierdza to powyżej wymienione zapotrzebowanie na dyskusję nad rolą samorządności w szkole. Wskazane są też działania ukierunkowane na ukazanie znaczenia samorządności w wychowaniu uczniów i kształtowanie liderów, którzy przejmą odpowiedzialność za społeczność lokalną i kraj.

Podsumowując badania nad samorządnością szkolną, należy stwierdzić, że jest to formuła działań wychowawczych raczej niewykorzystana. Mimo że daje olbrzymie szanse na rozwój przyszłych kadr liderskich, to w większości zajmuje marginalne miejsce w świadomości kadry szkolnej, ale i uczniów. 


\section{Bibliografia}

Gaś Z. (2013), Program Aktywizacji Samorzadu Uczniowskiego. Materiały edukacyjne dla uczestników projektu: „Samorządność szkolna inaczej - Program Aktywizacji Samorządu Uczniowskiego”, Ośrodek Rozwoju Człowieka i Psychoedukacji Fundacja „Masz Szansę", Lublin.

Goriszowski W. (2010), Samorzadność szkolna droga do demokracji w ujęciu historycznym, „Nauczyciel i Szkoła” 1-2(46-47), 83-92.

Kamiński A. (1985), Samorząd młodzieży jako metoda wychowawcza, PZWS, Warszawa.

Kuzitowicz W. (2017), Idea a praktyka uczniowskiej samorząności w polskich szkołach, http://obserwatoriumedukacji.pl/idea-a-praktyka-uczniowskiej-samorzadnosci-2/ [dostęp: 13.06.2017].

Radziewicz J., Miros M. (1988), O samorządności uczniów w procesie wychowania szkolnego, Nasza Księgarnia, Warszawa.

Samorządność uczniowska $w$ warszawskich szkołach. Raport z badania jakościowego przygotowany dla M. St. Warszawy (2009), Grupa IQS, Warszawa.

Stolarska A. (2005), Samorząd uczniowski nie może być fikcja, „Edukacja i Dialog”, 2, 68-72.

Ustawa z dnia 7 września 1991 r. o systemie oświaty [UoSO], Dz.U. z 1991 r. Nr 95, poz. 425. 